\title{
Participatory practices in natural and cultural heritage
}

\author{
Andrea A. Travaglia \\ Independent Researcher \\ University of Amsterdam, ACASA - Department of Archaeology, Amsterdam, the \\ Netherlands
}

\begin{abstract}
Heritage planning in Europe, through the Valletta and Florence Conventions, constitutes a framework for cooperation whereby the public is encouraged to take an active part - an ongoing cultural practice that includes society. Within this paper, I focus on participatory practice as a reflective process of problem-solving in heritage via individuals working together as a community of practice and crowd-based approaches. The recent development of the Environment and Planning Act (Omgevingswet) in the Netherlands, which will legally frame the way municipalities and citizens interact with their environment, is used as a case study to show context-dependent risks associated with the democratic dialogue in heritage planning. Participatory planning is impossible without democratic participation, and there is a risk that the Omgevingswet will merely pay lip service to participatory practice. I analyse engagement with technology and the new law that is not yet operational - with its influence on citizen participation yet to form - that could either have negative consequences or potentially enhance the participatory governance process in the Dutch heritage sector. In conclusion, the medium (Omgevingswet online platform) is the message (integration of sustainable Dutch landscapes in national and regional environmental visions) for online participatory practice in a networked information economy.
\end{abstract}

Keywords: The Netherlands, Environment and Planning Act, Omgevingswet, Natural and Cultural Heritage, Participatory Practice, Governance

\section{Introduction}

Participatory practices in archaeology can be difficult to pin down. There are recent case studies that show how citizens, communities and the public engage with their archaeological heritage (see Thomas and Lea 2014, Moshenska 2017, Jameson and Musteaţă 2019). Public participation can assume a flexible role that includes communities and public spaces, an engagement strategy that is aimed at the general public. But when it comes to natural and cultural heritage, do participatory practices adopt strategies for qualitative and meaningful civic engagement? Or offer a format that could equally enhance heritage discourse? Through an interdisciplinary approach to natural and cultural heritage research, this paper examines new ways of perceiving governance as a theoretical idea and framework for practice and the associated risks and challenges. 
Heritage is not static; it shapes itself around broader spatial developments and cultural changes (Lowenthal 1996). This paper discerns how environmental planning connects to natural and cultural heritage practice. Heritage management that privileges monumentality and site significance tied to time depth, expert judgement and nation-building is a selfreferential discourse that has consequences (Smith 2006: 11). And whether or not heritage is threatened by environmental, legal, political, or commercial processes, new initiatives make it possible for (digital) conservation and wider collaboration - the heritage sector's battle-cry for future generations and preconditions for participatory practice.

\section{Public participation}

Heritage dialogue in the Netherlands between public authorities and experts, local residents and other stakeholders is an example of a process referred to as participatory planning (Elerie \& Spek 2010: 93). The premise being that setting goals together can formulate policy. The role of science in Dutch policy recognises that academic knowledge plays an important part in the transdisciplinary process when decisions are being made in the Netherlands regarding archaeology (Van der Valk \& Bloemers 2006: 30). Active research is specifically recognised as a reflective process of progressive problem solving, which is led by individuals working with others as part of a community of practice (CoP) to improve the way issues and problems are solved (Elerie \& Spek 2010: 92). The concept of a CoP, at the core of social theory, is about learning. But learning is more than just acquiring knowledge; it involves ongoing interaction with others to share and collaborate.

A CoP can be viewed as a strategy. It provides a framework to explore learning in organisations and improve upon practices within them. Participatory planning is one example of a problemsolving process where individuals work in teams or as part of a CoP to improve their practice. A CoP enables individuals with diverse backgrounds and interests to productively work together on common goals. Individuals devoted to maintaining, restoring and reviving natural and cultural heritage may form a CoP, cooperating for shared political or economic interests (Adell et al. 2015: 7-18). A CoP for natural and cultural heritage can produce beneficial stewardship through a shared repertoire of knowledge that can also be passed on to new members. The potential challenges of a CoP should also be recognised, including the amount of time available to adequately engage in an activity to reach a specific goal as well as the wider socio-cultural environment in which a project is situated for an effective CoP.

\section{Crowd-based initiatives}

When it comes to cooperating on an online platform, the main issue is how participation can be designed to get specific results. This relies on the crowd. Crowd-based initiatives (more commonly known as crowdfunding and crowdsourcing) are strategies for public outreach and participation. These tools can be used to gain project funding and can benefit from the skills of the wider public who have competencies across various disciplines. Over the past fifteen years, there has been a paradigm shift within global heritage discourse. An adjustment that acknowledges the dominant role of experts - defining heritage values and broadcasting knowledge - and moves towards experts actively engaging with citizens, communities and the public to incorporate more divergent voices in heritage. 
Recent examples can be seen in the crowd-based campaigns for natural and cultural heritage:

- funding research - the University of Amsterdam has been participating in the renewed crowdfunded excavations at Troy (Van Wijngaarden et al. 2016);

- contributing data - SciStarter, an online community dedicated to improving the citizen science experience for project managers and participants (SciStarter 2019);

- transcription - MicroPasts, an online platform that allows archaeology professionals and enthusiasts to collaborate (Bonacchi et al. 2014);

- field excavations - DigVentures, a social business that specialises in crowdfunding, crowdsourcing and digital methods to increase public participation in archaeological research and heritage projects in the UK, Europe and the United States (DigVentures 2012), and CARE, community archaeology in the Netherlands (CARE 2018);

- environmental monitoring - NASA, an open global inventory of landslides (NASA 2018);

- taking part in publications as co-creators - Zooniverse, enabling people to participate in research fields across the sciences and humanities (Zooniverse 2009);

- monitoring and protecting natural and cultural heritage - SCHARP in Scotland (Graham et al. 2017).

Relationships between experts and the public (including 'the crowd') are changing in many sectors, predominantly through the adoption of technology. This, in turn, allows for the flourishing of competing interests and opinions. These relatively new crowdbased approaches have been 'unlocked' by technological developments and have provided alternative funding possibilities to public grants. The Internet-based crowdfunding platform has eliminated most distance-related economic frictions normally associated with financing early-stage projects such as acquiring information, monitoring progress and providing input (Agrawal et al. 2011: 3). The use of crowdfunding is also a way to help reduce market failures (Agrawal et al. 2011: 18).

For the cultural heritage sector, engaging in information-sharing and online dialogue begins with an understanding of how information about the past is sought, processed, received, interpreted, associated, subverted and recycled through the Internet (Richardson 2013: 8). Cultural heritage crowdsourcing is an emerging form of engagement that contributes towards shared goals and research, where projects can be a platform for audience engagement, offering a valuable connection to heritage through online collaboration (Ridge 2013: 435).

This does not mean welcoming pseudo-scientific evidence that lacks expert evaluation. It means more opportunities for people to work with their own set of specialised skills from different disciplines, which can bring a breadth of expertise to a project. Crowd-based initiatives might not be for everyone. Creating relationships with the crowd might not be for everyone either. But natural and cultural heritage relates to us and our shared environment, so the values we have and the platforms we use will frame our collective future. 


\section{Case study: The Environment and Planning Act (Omgevingswet)}

In 2016, the Dutch government passed a bill in the Netherlands that will affect the future integration of natural and cultural heritage. The new environmental law, which will come into effect in 2021, merges all regulations into one Environment and Planning Act (Omgevingswet). It stipulates that citizens, companies and social organisations must be able to participate in the early stages of the decision-making process with regard to a project or activity (Ministerie van Infrastructuur en Milieu 2016b: 103-104). One of the stated goals of the new act is to make it easier for citizens to set up their own initiatives, allowing them to have more say about their local environment (Ministerie van Infrastructuur en Milieu 2016b: 6). Another is to facilitate public participation (Ministerie van Infrastructuur en Milieu 2016b: 11). The law, however, is not clear on how public participation will be achieved.

Currently, some municipalities have over 100 land-use plans. The Dutch government claims that a single environmental plan for an area will replace multiple zoning plans with fewer regulations because the Omgevingswet will make it possible to solve local problems locally (Rijksoverheid 2018). With the new law, tasks will be delegated towards the municipal level. Municipalities will have differing ideas about granting permits and halting soil-disrupting activities in the case of archaeological finds of general interest (Rijksdienst voor het Cultureel Erfgoed 2019). The Omgevingswet asks for a new role of the municipalities, not only to be primarily responsible for the physical environment but also adapt to a different cultural attitude of bottom-up planning.

Article 23.4 of the Legislative Bill states that for a period of at least four weeks, all persons shall be given an opportunity to submit comments (by electronic means) regarding a draft project decision during the early exploration stage (Ministerie van Infrastructuur en Milieu 2016a: 73). While citizens are offered the chance, albeit brief, to engage in preliminary plans, there is a presumption that citizens will have the opportunity and digital skills to do so. However, this early form of public participation is about collaborating with stakeholders and discovering the risks and opportunities at the start of a project so that research costs can be decreased, the planning process can be accelerated, and local and expert knowledge can be used at an early stage (Aan de slag met de Omgevingswet 2019a).

The Valletta Convention (Council of Europe 1992) and the Florence Convention (Council of Europe 2000) already provide a pan-European framework for cooperation on natural and cultural heritage. From an ideological point of view, the notion that citizens can participate in their own heritage resonates with the Faro Convention (Council of Europe 2005) and the Aarhus Convention (United Nations Economic Commission for Europe 2001). It also coincides with participatory practices and crowd-based initiatives in Europe that have been developing over recent years in natural and cultural heritage (see European Commission 2017). From a practical point of view, there is no indication of how the Omgevingswet will be integrated with the current fragmented model of natural and cultural heritage in the Netherlands, with its many procedures and rules. In the new system, heritage must be approached coherently because the management of a heritage site is not only about the physical environment itself but also about the activities planned in and around it (UNESCO Werelderfgoed in Nederland 2018: 7). This implies that the future of heritage must be unified, especially since the new law will enshrine World Heritage into Dutch law for the first time (UNESCO Werelderfgoed in Nederland 2018: 8). 


\section{Expectations}

Within the context of preparing an environmental plan, municipalities take into account cultural heritage, including anticipated archaeological assets (Ministerie van Infrastructuur en Milieu 2016b: 73). While it is the responsibility of municipalities to make anticipated assets as clear as possible beforehand, it is not always so obvious in practice. While the Omgevingswet requires initiators (including the private sector) to conduct research (soil investigations, for example), the data will be valid for longer, making it easier to use again (Rijksoverheid 2018). The idea is that this would create a better means for digital recording and availability of plans through standardisation via Social Impact Assessments (SIA) (International Finance Corporation 2012), a new process in the Netherlands as a result of the Omgevingswet.

The SIA standard is based on environmental impact reporting, consultation, and public participation at various levels - integrating plans that anticipate environmental and social risks posed by project activities - and potentially uniting participatory practice with natural and cultural heritage in the Netherlands. According to the Dutch government, future assessments under the Omgevingswet will also be more transparent via the new online portal for initiators to find out which provisions apply, which procedures must be followed, and which competent authority grants the permit (Overheid 2016).

The role of the national government is shifting from governing to facilitating the planning processes of regional and local authorities, and the Omgevingswet transition requires the support of municipalities. Local government regulations must be included in the online system, which means all authorities have to translate their legal rules from environmental plans, environmental regulations and water board regulations into applicable rules (Aan de slag met de Omgevingswet 2019b). What is fundamentally different from the currently accepted model is that citizens will be able to participate and even initiate projects of their own. Whether this will be straightforward in practice is another question.

There is no clear-cut outline yet for the ongoing process of implementing public participation in the Omgevingswet. It is uncertain what public participation will look like, but a shift in thinking and looking beyond one's own domain, treating the environment as a whole, is what the Omgevingswet encourages. This organisational structure of citizen participation will be compulsory by law and might allow the future vision of sustainability, and interdisciplinary knowledge-generating processes, to evolve.

\section{Example}

The Dutch government has created the National Environmental Vision (Nationale Omgevingsvisie, NOVI) (Ministerie van Binnenlandse Zaken en Koninkrijksrelaties 2019a), which is instrumental to the Omgevingswet. The NOVI, a vision for the whole of the Netherlands, describes a long-term plan that outlines the development, use, management, protection, and conservation for future policy. However, the Dutch government cannot and does not want to answer the big questions about the physical living environment alone, so the NOVI is an ongoing process that is closely cooperating with local authorities, actively seeking the involvement of social organisations, knowledge institutions and residents (Ministerie van Binnenlandse Zaken en Koninkrijksrelaties 2019b).

On a national level, the NOVI focuses on a sustainable and competitive economy, a climateproof and climate-neutral society, a future-proof and accessible living/working environment, 
and a valuable living environment (Ministerie van Infrastructuur en Milieu 2017: 47). The ambition to preserve and maintain heritage for future generations can be at odds with the desire to change and intensify the use of the living environment. However, the NOVI pays particular attention to the interface between sustainability and heritage. For example, a broad definition of cultural heritage in the physical living environment is used. The idea is to keep monuments, historical buildings, village views and cultural landscapes for future use, incorporating sustainability and smart design - a tool that contributes to the quality and guides the future of the living environment (Ministerie van Infrastructuur en Milieu 2017: 30-31). While the NOVI is a long-term national strategic plan for the Netherlands, the municipalities have to create environmental strategies that coincide with its focus.

On a regional level, to strengthen cohesion between municipalities that must build on the NOVI, a cooperation agenda for the city of Leiden and its surrounds has already been drawn up to create a regional environmental vision - Regionale Agenda Omgevingsvisie 2040 (Van Der Straaten 2016). Along with Leiden, the cooperating municipalities include Kaag and Braassem, Katwijk, Leiderdorp, Noordwijk, Oegstgeest, Teylingen, Voorschoten, Wassenaar, and Zoeterwoude. This municipal coalition was not appointed on an ad hoc basis; it had to form out of necessity to comply with the future regional vision of the landscape in which they share.

This regional agenda describes the intention of the Omgevingswet - combining themes that include construction works, buildings, infrastructure, water systems, water, soil, air, landscapes, natural and cultural heritage - as an integral vision of the physical living environment and taking into consideration the reuse of built heritage in the region (Van Der Straaten 2016: 22). Furthermore, the municipalities recognise the Netherlands as a human-made cultural landscape - remodelling, maintaining, developing, and integrating natural and cultural heritage in development (Van Der Straaten 2016: 10). Therefore, it is not surprising that this regional vision by the municipal coalition includes the cultural-historical and archaeological values of the Limes, once the northern border of the Roman Empire along the Old Rhine, as an important feature in the landscape to be preserved for the future (Van Der Straaten 2016: 41). This regional vision is an example that shows how municipalities can communicate with each other and with citizens (those who are both willing and have the time to do so) who also have ideas and preferences for their local environment, encouraging public participation in regional environmental planning.

\section{Analysis}

Obvious or not, one cannot assume that everyone has an equal opportunity to be involved in a regional vision (some still in development) or a proposed project on the new Omgevingswet online portal. The extent to which citizens can and want to participate, especially if it is only limited to the early stages of a plan or project, can affect the outcome of how natural and cultural heritage will be integrated with the landscape too, and this will differ from municipality to municipality and region to region.

The precise format for public participation through the new Omgevingswet online portal, where interaction will occur, is not yet available. However, within the new law, the online platform will allow citizens to apply for an environmental permit and update citizens about the progress of a project. The online platform will also be used for discussions among stakeholders, educating local officials, and providing options for citizens to report issues 
in their local environment (Aan de slag met de Omgevingswet 2019c). Since the new law is not yet operational, its influence on citizen participation is yet to take shape. But the incorporation of knowledge and expertise of citizens in the planning processes (presuming that participation is equal and accessible to all citizens), which may be specifically related to local knowledge that is unavailable to governmental organisations, could lead to beneficial outcomes for participatory practice in that information is made transparent at municipal, regional and national levels.

The internal changes in local, regional and national governmental organisations are required to move away from current bureaucracy practice and acclimate to new working processes on the Omgevingswet digital platform, along with new methods of communication. Because citizens will have the opportunity to become partners in the planning process, the dialogue between governmental institutions and citizens could potentially enhance the participatory governance process.

Participatory governance refers to the sharing of institutional decision making with the wider public. Governance structures within cultural heritage organisations usually do not offer the public any formal role, thus limiting their long term impact (Sani 2015: 7). A participatory approach requires adjustments in the structure of governance, along with a change in the organisational structure of institutions, ceding their authority and giving stakeholders an opportunity to have their say (Sani 2015: 9). While these strategies may be inclined to follow bottom-up principles, a participatory process of governance does not have to be either topdown or bottom-up; it can be both.

If the NOVI and regional environmental visions are the grounds for which choices are being made in the environmental planning process, projects should involve a continuous process of participation where citizens and other stakeholders are (or can be) involved in an ongoing way - not just in the early stages. This also raises the question as to whether every initiator of a project is even capable and required to guide the participation process, or if that is the responsibility of the municipalities. The Omgevingswet does not make this explicitly clear.

\section{Opinion}

If the NOVI indicates how municipalities will guarantee the protection of natural and cultural heritage for the long term, cultural-historical and archaeological values should be clearly described in future examples of municipal regional environmental visions and agendas from the outset. Natural and cultural heritage could be framed as 'additional' value to local environmental projects. Decisions should also be based on the best available knowledge and involve citizens in all phases of the decision-making process. If the goal is not to simply inform citizens about projects, but provide details on the how and the why, information exchange can bring citizens together for the purpose of sharing ideas and concerns. Real citizen participation involves the dissemination of information.

If the online Omgevingswet platform succeeds in decentralising power, shifting responsibility from the government to the public, it cannot be assumed that community decision making is monolithic. The Omgevingswet is going to replace current laws, and the expectation might be that both natural and cultural heritage values will become more equally integrated in the Netherlands, particularly when World Heritage (UNESCO 2019) will be enshrined into Dutch law. And while perhaps the Omgevingswet is genuinely optimistic about its pragmatism, it may 
be simply paying lip service to the term participatory practice. Only time will tell how well the integration of laws from various sectors, including natural and cultural heritage, will fair.

Power struggle: case-by-case basis

Public participation is a paradox. Significant questions arise as to who gets to decide the rules of shared spaces and who gets to shape the tools and platforms. The Omgevingswet implies that the online platform is open to involve all citizens. However, the application of crowd-based initiatives (one of many potential outcomes for the future Omgevingswet online portal), involves knowledge: knowledge for its own sake and the practical applications of knowledge, knowledge as collaborative practice, both of which are required in order to bring about smart courses of future engagement. If the objectives, scope and purposes are clear from the outset, and if a project is made continually clear throughout its development, then there might be a higher chance of civic involvement. It cannot be assumed, however, that increased online involvement is one of the main goals of the Omgevingswet.

There are valid concerns that crowdsourcing and crowdfunding methodologies could substitute insight for engagement (Tourle 2017: 237). This consideration can also be applied to the online Omgevingswet platform, alongside the production and consumption of natural and cultural heritage and privileged access to funds and digital technologies. The ramifications of a crowd-based practice could potentially devalue professional labour by replacing it with free labour (Perry \& Beale 2015, Richardson 2017). For these reasons, crowd-based projects should be flexible.

The participatory practice of crowd-based initiatives does not replace traditional heritage management but acts as another avenue for heritage discourse and practice. Depending on the project, crowd-based approaches may not even be required, or one approach might be more necessary than the other. It is context-dependent; one size does not fit all. Associating a project with learning institutions such as universities, vocational training schools, museums, libraries, or the city archives can enhance its quality by gaining access to other resources (Travaglia 2015: 76). Whether or not heritage is at the mercy of destruction by political, natural or commercially induced processes, crowd-based initiatives can make it increasingly possible for the public to get involved and be stewards of their own heritage.

\section{Summary: natural and cultural heritage}

If participants have the opportunity to be engaged, rewards for enforcing the governance of a project could create new value, especially in the Netherlands, where the Omgevingswet will allow for the interplay of citizens, professionals, municipalities, the private sector and the government to co-create. With the Omgevingswet in place, research data will remain valid for longer (in theory), which will also make it easier to (re)use.

When it comes to participatory practice, it is uncertain whether the Omgevingswet will use strategies that include a community of practice or crowd-based approaches. What this means for the future of natural and cultural heritage is unclear. Perhaps the Omgevingswet will ensure integration of natural and cultural heritage because it perceives itself as eliminating the bureaucracy that is associated with the overlapping sectors of nature and culture.

The NOVI and regional environmental visions (one of which was mentioned within this paper) that prioritise certain landscape values over others, matter. The way a project is framed 
can influence the perspectives of citizens and experts alike. The Omgevingswet will provide a new digital platform of participation and perhaps both the public and the government will equally control it. This will depend on the way municipalities integrate heritage in their regional visions, by communicating through a digitally layered platform that is still under development.

\section{Conclusion}

Technology can change society's values and norms. Online communities and networks are globally transforming the way people do things - from vertical, top-down and centralised to horizontal, bottom-up and decentralised. But how does this translate to the natural and cultural heritage discourse? To quote communications theorist Marshall McLuhan, "the medium is the message" (McLuhan et al. 1967). The way public participation influences natural and cultural heritage discourse will depend on the medium.

The medium, such as the online Omgevingswet platform, embeds itself in the message, such as the integration of sustainable landscapes in a national environmental vision (NOVI). The regional vision example (Van Der Straaten 2016) combines natural and cultural heritage in the physical living environment. However, other regional visions may also overlap, but are yet to be made available. There is a symbiotic relationship whereby the medium (the Omgevingswet as a combining law and as an online platform of engagement) can influence how the message (the national and regional environmental visions with a long-term view for the future and development of the environment) is perceived by the public.

The medium is not neutral; it has a social impact. It is yet to be determined what effects the Omgevingswet medium will have on society. The process of participatory practice, in consultation with citizens and experts both online and offline, can be complementary. But consider this: if decentralised representation in governance is less democratic than what is currently on offer for those participating in the heritage dialogue, the potential risk of the Omgevingswet paying lip service to participatory practice will have a profoundly negative effect on how democratic the dialogue in heritage planning will be. While the multiplication of participatory practices in heritage is no guarantee for the redistribution of democratic powers, one message is clear - new initiators and initiatives could make it increasingly possible for wider collaboration, engagement and insight.

\section{References}

Aan De Slag Met De Omgevingswet, 2019a. Participatie in de Omgevingswet. Accessed 05/12/2019. https://aandeslagmetdeomgevingswet.nl/thema/participatie/participatie-wet/. Aan De Slag Met De Omgevingswet, 2019b. Vergunningcheck in het Omgevingsloket. Accessed 05/12/2019. www.aandeslagmetdeomgevingswet.nl/digitaal-stelsel/in-de-praktijk/ bouwstenen-stelsel/omgevingsloket/vergunningcheck.

Aan De Slag Met De Omgevingswet, 2019c. Omgevingsloket: dit houdt het in. Accessed 05/12/2019. https://aandeslagmetdeomgevingswet.nl/digitaal-stelsel/in-de-praktijk/ bouwstenen-stelsel/omgevingsloket/.

Adell, N., Bendix, R. F., Bortolotto C. \& Tauschek, M., 2015. Introduction: Between Imagined Communities and Communities of Practice: Participation, Territory and the Making of Heritage, in: N. Adell, R. F. Bendix, C. Bortolotto \& M. Tauschek (eds), Between Imagined Communities of Practice: Participation, Territory and the Making of Heritage. 
Göttingen University Press, 7-18.

Agrawal, A. K., Catalini, C., \& Goldfarb, A., 2011. The Geography of Crowdfunding, National Bureau of Economic Research Working Papers 16820, University of Toronto.

Bonacchi, C., Bevan, A., Pett, D., Keinan-Schoonbaert, A., Spark, R., Wexler, J. \& Wilkin, N., 2014. Crowd-sourced Archaeological Research: The MicroPasts Project. Archaeology International, 17, 61-68.

CARE, 2018. Gemeenschapsarcheologie in Het Groene Woud. Accessed 05/12/2019. https:// gemeenschapsarcheologie.nl/hoe-werkt-het/.

Council Of Europe, 1992. Convention for the Protection of the Archaeological Heritage of Europe (revised) (Valletta, 1992). Accessed 05/12/2019. https://www.coe.int/en/web/culture-andheritage/valletta-convention.

Council Of Europe, 2000. The European Landscape Convention (Florence, 2000). Accessed 5/12/ 2019. https://www.coe.int/en/web/landscape/the-european-landscape-convention Council Of Europe, 2005. Convention on the Value of Cultural Heritage for Society (Faro Convention, 2005). Accessed 5 Dec 2019: https://www.coe.int/en/web/culture-and-heritage/faroconvention

Digventures, 2012. Accessed 05/12/2019. https://digventures.com/about-us/.

Elerie, H. \& SpeK, T., 2010. The Cultural Biography of Landscape as a Tool for Action Research in the Drentsche Aa National Landscape (Northern Netherlands), in: T. Bloemers, K. Henk, A. Van Der Valk (eds), The Cultural Landscape \& Heritage Paradox. Amsterdam, Amsterdam University Press, 83-113.

European Commission, 2017. Crowdfunding: Reshapingthe Crowd's Engagementin Culture. Accessed 31/10/2019. https://op.europa.eu/en/publication-detail/-/publication/7e10916d-677c11e7-b2f2-01aa75ed71a1/language-en.

Graham, E., Hambly J. \& Dawson, T. 2017. Learning from Loss: Eroding Coastal Heritage in Scotland. Humanities 2017, 6(4), 87.

International Finance Corporation, 2012. Assessment and Management of Environmental and Social Risks and Impacts. Accessed 05/12/2019. https://www.ifc.org/wps/wcm/connect/ topics_ext_content/ifc_external_corporate_site/sustainability-at-ifc/policies-standards/ performance-standards/ps1.

Jameson, J. \& Musteață S. (eds), 2019. Transforming Heritage Practice in the 21st Century. Springer International Publishing.

Lowenthal, D., 1996. The Heritage Crusade and the Spoils of History. London: Cambridge University Press.

Mcluhan, M., Fiore, Q., \& Agel, J., 1967. The Medium is the Massage. New York: Bantam Books.

Ministerie Van Binnenlandse Zaken En Koninkrijksrelaties, 2019a. Ontwerp Nationale Omgevingsvisie Duurzaam perspectief voor onze leefomgeving. Accessed 31/10/2019. https://www.denationaleomgevingsvisie.nl/PageByID. aspx?sectionID $=191952 \&$ contentPageID $=1452074$

Ministerie Van Binnenlandse Zaken En Koninkrijksrelaties, 2019b. Wat is de Nationale Omgevingsvisie (NOVI)? Accessed 5/12/ 2019. https://www.denationaleomgevingsvisie.nl/ over+novi/default.aspx

Ministerie Van InfrastructuUr En Milieu, 2016a. Translation of the Environment and Planning Act Legislative Bill. Accessed 31/10/2019. https://www.government.nl/ binaries/government/documents/reports/2017/02/28/environment-and-planning-act/ EnglishtranslationEnvironmentAct.pdf. 
Ministerie Van Infrastructudr En Milieu, 2016b. Translation of the Environment and Planning Act Explanatory Memorandum. Accessed 31/10/2019. https:// www.government.nl/binaries/government/documents/reports/2017/02/28/ environment-and-planning-act-\%E2\%80\%93-explanatory-memorandum/ EnglishtranslationExplanatorMemorandumEnvironmentAct.pdf.

Ministerie Van Infrastructudr En Milieu, 2017. De opgaven voor de Nationale Omgevingsvisie. Accessed 31/10/2019. https://www.rijksoverheid.nl/documenten/ beleidsnota-s/2017/02/17/de-opgaven-voor-de-nationale-omgevingsvisie Moshenska, G. (ed.), 2017. Key Concepts in Public Archaeology. London: UCL Press.

NASA, 2018. The Cooperative Open Online Landslide Repository (COOLR) project. Accessed 5/12/2019. https://pmm.nasa.gov/landslides/about.html.

OVERHEID, 2016. Omgevingsbeshit (AMvB Omgevingswet). Accessed 31/10/2019. https:// www.internetconsultatie.nl/omgevingswet_omgevingsbesluit/details

Perry, S. \& Beale, N., 2015. The Social Web and Archaeology's Restructuring: Impact, Exploitation, Disciplinary Change. Open Archaeology 1(1), 153-165.

Richardson, L., 2013. A Digital Public Archaeology? Papers from the Institute of Archaeology, 23(1), p.Art. 10, 1-12.

Richardson, L., 2017. I'll Give You 'Punk Archaeology', Sunshine. World Archaeology 49 (3), 306-317.

Ridge, M., 2013. From Tagging to Theorizing: Deepening Engagement with Cultural Heritage Through Crowdsourcing. Curator: The Museum Journal, 56 (4), 435-450.

Rijksdienst Voor Het Cultureel Erfgoed, 2019. Erfgoed in de Omgevingswet. Accessed 5/12/ 2019.

https://www.cultureelerfgoed.nl/onderwerpen/omgevingswet/erfgoed-in-deomgevingswet.

RIJKSOVERHEID 2018. Nieuwe omgevingswet maakt omgevingsrecht eenvoudiger. Accessed 31/10/2019. https://www.rijksoverheid.nl/onderwerpen/omgevingswet/vernieuwingomgevingsrecht.

SANI, M., 2015. Participatory Governance of Cultural Heritage, European Expert Network on Culture. Accessed 31/10/2019. http://www.interarts.net/descargas/interarts2538.pdf.

SCISTARTER, 2011. Accessed 5/12/2019. https://scistarter.org/about.

Sмith, L., 2006. Uses of Heritage. London, Routledge, Taylor \& Francis Group.

Thomas, S. \& LeA, J. (eds), 2014. Public Participation in Archaeology. Boydell and Brewer.

Tourle, P., 2017. White Noise: Sound, Materiality and the Crowd in Contemporary Heritage Practice. International Journal of Heritage Studies 23 (3), 234-247.

Travaglia, A., 2015. Archaeology and the Crowd. An Exploration of Socially Responsible Archaeology (MA Thesis). University of Amsterdam \& Vrije University (ACASA). Accessed 31/10/2019. https://www.academia.edu/15482525/Archaeology_and_the_Crowd_An_Exploration_ of_Socially_Responsible_Archaeology.

UNESCO 2019, Netherlands. Accessed 5/12/2019. https://whc.unesco.org/en/ statesparties/nl.

UNESCO Werelderfgoed in Nederland, 2018. Verslag Unesco Werelderfgoed Bestuurdersdag 2018: De Wederkerigheid van Werelderfgoed, 7-11-2018 van Nellefabriek Rotterdam. Accessed 31/10/2019. https://www.unesco.nl/sites/default/files/inline-files/Verslag\%20Werelderfgoed $\% 20$ Bestuurdersdag.pdf.

United Nations Economic Commission For Europe, 2001. Public Participation. Accessed 5/12/2019. https://www.unece.org/env/pp/welcome.html. 
Valk, A. Van Der \& Bloemers, T., 2006. Multiple and Sustainable Landscapes: Linking Heritage Management and Spatial Planning in the Netherlands, in: W. VAn Der KnaAp \& A. Van Der Valk (eds), Multiple Landscape. Merging Past and Present. Wageningen, 21-33.

Van Der Straaten, P., 2016. Hart van Holland Regionale Agenda Omgevingsvisie 2040. Accessed 31/10/2019. https://gemeente.leiden.nl/bestanden/omgevingsvisie-2040.pdf.

Van Wijngaarden, G., Thoirealaigh, A.N. , Gerritsen, V., Magdelijns, N. \& Rendering, B., 2018. Troy: Archaeology of Archaeology. Accessed 5/12/2019. https://experiment.com/ projects/troy-archaeology-of-archaeology.

ZOONIVERS, 2009. Accessed 5/12/2019. https://www.zooniverse.org/about. 